\title{
NO PLACE LIKE HOME: OLDER ADULTS AND THEIR HOUSING
}

\author{
Timothy Smeeding, Barbara Boyle Torrey, Jonathan Fisher, \\ David S. Johnson, and Joseph Marchand*
}

CRR WP 2006-16

Released: August 2006

Draft Submitted: June 2006

\author{
Center for Retirement Research at Boston College \\ 550 Fulton Hall \\ 140 Commonwealth Ave. \\ Chestnut Hill, MA 02467 \\ Tel: 617-552-1762 Fax: 617-552-1750 \\ http://www.bc.edu/crr
}

* Timothy Smeeding is the Director of the Center for Policy Research at Syracuse University. Barbara Boyle Torrey is a Visiting Fellow at the Population Reference Bureau. Johnathan Fisher is a Research Economist at the Bureau of Labor Statistics. David S. Johnson is the Chief of Housing and Household Economic Statistics Division at the Census Bureau. Joseph Marchand is a Ph.D. candidate in economics at Syracuse University. The research reported was performed, in part, pursuant to a grant from the U.S. Social Security Administration (SSA) funded as part of the Retirement Research Consortium. The findings and conclusions expressed are solely those of the authors and do not represent the views of SSA, any agency of the Federal government, the Bureau of Labor Statistics, Census Bureau, the Center for Policy Research, the Population Reference Bureau, or Boston College. The authors want to thank the Center for Retirement Research at Boston College and the Social Security Administration for their support of this research. Kati Foley provided excellent help with graphics and table design, and Martha Bonney provided much needed editorial assistance. Helpful references were made by John Quigley and Edgar Olsen.

(C) 2006, by Timothy Smeeding, Barbara Boyle Torrey, Johnathan Fisher, David S. Johnson, and Joseph Marchand. All rights reserved. Short sections of text, not to exceed two paragraphs, may be quoted without explicit permission provided that full credit, including (C) notice, is given to the source. 


\section{About the Center for Retirement Research}

The Center for Retirement Research at Boston College, part of a consortium that includes a parallel centers at the University of Michigan and the National Bureau of Economic Research, was established in 1998 through a grant from the Social Security Administration. The goals of the Center are to promote research on retirement issues, to transmit new findings to the policy community and the public, to help train new scholars, and to broaden access to valuable data sources. Through these initiatives, the Center hopes to forge a strong link between the academic and policy communities around an issue of critical importance to the nation's future.

\section{Center for Retirement Research at Boston College \\ 550 Fulton Hall \\ 140 Commonwealth Ave. \\ Chestnut Hill, MA 02467 \\ phone: 617-552-1762 fax: 617-552-0191 \\ e-mail: crr@bc.edu \\ http://www.bc.edu/crr}

\section{Affiliated Institutions:}

American Enterprise Institute

The Brookings Institution

Center for Strategic and International Studies

Massachusetts Institute of Technology

Syracuse University

Urban Institute 


\begin{abstract}
Objectives: The home of older Americans is both their largest asset and their largest consumption good. This paper employs new data on the consumption and assets of older Americans to investigate what role the home plays in the economic lives of older adults.
\end{abstract}

Methods: We use 20 years of data from the Consumer Expenditure Survey to examine the asset and consumption trends of four cohorts of older Americans. The data are compared with other survey results.

Results: Older American’s homeownership rates are stable until age 80. The homes are increasingly mortgage-free; home equity increases with age, and relatively few older adults take out home equity loans or reverse annuity mortgages. Housing consumptionflows increase with age; non-housing consumption-flows decline after age 60 at a rate of approximately 1.4 percent a year.

Discussion: The results suggest that the consumption of cohorts of older Americans does not decrease dramatically over a 20-year period and they are also not converting their housing assets into other types of income or consumption, at least up to age 80. A number of reasons might explain this behavior, including the bequest motive and the lifecycle hypothesis. 


\section{INTRODUCTION}

The single largest asset of older adults is their home. In addition to being the single largest asset, the home is also the single largest item in their consumption bundle. Therefore, the home is central to the economic calculations older Americans must make over time. And how they manage their housing assets and consumption gives insight into their motivations and the incentives they face as they age.

How the older population manages their housing assets and consumption can be interpreted from many different perspectives including the life-cycle hypothesis, a financial portfolio perspective, a bequest motive, and a socioemotional selectivity perspective. This paper will contribute new data and findings but no resolution among the different perspectives. It, however, illuminates some of the economic trends of the older population over time and raises questions for further research.

We use a data set, the Consumer Expenditure Survey (CEX), which has not been used before to investigate the economic role of older adults' homes. We discuss the comparative strengths and weaknesses of the CEX data set and compare our results to others, including those based on the American Housing Survey (AHS) and the Survey of Consumer Finances (SCF). We then describe the asset and consumption trends of four cohorts of older Americans over the last 20 years. Finally, based on the CEX data, we discuss possible reasons for the trends and their implications.

\section{BACKGROUND}

The life-cycle hypothesis is perhaps the best known perspective with which to view the housing behavior of the older population. It predicts that individuals will smooth consumption over their lifetime, saving when they are working and then using their savings and assets (such as 
their home) to maintain their consumption after their income declines in retirement (Modigliani and Brumberg, 1954). Recent research suggests that the actual behavior of the older population may be more complicated than the simple form of the hypothesis suggests.

Recent work using the Asset and Health Dynamics Among the Oldest Old (AHEAD) and the Health and Retirement Survey (HRS) suggests that housing equity for those who continue to own a home does not decline as they age (Venti and Wise, 2002, 2004). This is consistent with the research of Anderson, French, and Lam (2004) that also used the AHEAD and found that older adults do not run down their assets in later life, although the dynamics are different for married couples than for singles. These data show, however, that people do reduce their housing equity when facing major changes such as death or moving into a nursing home (Venti and Wise, 2002, 2004; Walker, 2004).

Kutty (1998) used the American Housing Survey (AHS) to examine the characteristics of older American's homes and demonstrated how reverse annuity mortgages (RAMs) could be used by them to convert housing assets into consumption. But Kutty finds that few older adults use RAMs, home equity loans, or second mortgages. A study using the Survey of Consumer Finances (SCF) concluded that the ratio of mortgage debt to income has increased considerably between 1989 and 2001 for households 55 and over (Masnick, Di, and Belsky, 2005). They speculated that this might increase the likelihood that older adults will use reverse equity mortgages or second mortgages to convert their equity into future consumption but present no evidence of such conversions.

Another perspective on why older people may not be reducing their assets is because of a bequest motive, the desire to leave a bequest to the next generations. If the older population wanted to leave an inheritance, they might treat their home as one part of their financial 
portfolio, which they are attempting to maximize. Hoynes and McFadden (1997) used the Panel Study of Income Dynamics (PSID) to ask whether the increase in housing values changed the financial savings of homeowners. They concluded that savings did not change much with the increase in housing values, suggesting housing assets were not treated as a substitute for other financial assets. On the other hand Bucks, Kennickell, and Moore (2006) using the 2004 SCF find that housing values have risen relative to the value of other assets and are becoming an increasingly larger share of financial portfolios among older adults. This suggests that the home may be a strong performing asset in the older population's investment portfolio and therefore an asset which might be held for investment returns alone.

It is also possible that the older population is treating their home not primarily as an asset or an investment but more as a meaningful consumption good. Socioemotional selectivity theory suggests that as time horizons shorten, motivations and incentives change. The shorter the time horizons, the more people, both young and old, look for emotional meaning in their life goals (Carstensen, 2006). If the home holds emotional meaning for older Americans, then holding on to the home may be more important than leaving a bequest or expanding their financial portfolio.

Our study will add new evidence to be used to address these different perspectives, but because of data limitations it cannot reconcile them.

\section{DATA AND METHOD}

Because the home is both the most important asset and consumption good of older adults, we cannot understand their economic behavior without understanding the dual role housing plays. This dual nature of housing is not a new observation; Henderson and Ioannides (1983) recognized it more than twenty years ago. Most empirical research on the home, however, has been on its role as an asset (Skinner, 1996; Venti and Wise, 2002, 2004; Walker, 2004; and 
Bucks, Kennickell, and Moore, 2006). Several recent studies have focused on the consumption of older adults, in which housing is an important component (Johnson, Smeeding and Torrey, 2005; Butrica, Goldwyn, and Johnson, 2005; Fisher, Johnson, Marchand, Smeeding, and Torrey, 2005; and, Munnell and Soto, 2005). This recent work has consistently shown that the home is the most important item in total consumption of older adults and that the value of imputed rent for their home has risen over time relative to other consumption flows.

The challenge in understanding the role of housing of older adults is to examine it as an asset and as a consumption good simultaneously, as they themselves do. Few data sets, however, have the kind of long term, consistent measurement of both consumption and assets that would guarantee that the calculations of housing assets and housing flows would be internally consistent. The Consumer Expenditure Survey (CEX) used in this paper meets those requirements and has not been utilized to study these questions. The comparative advantage of the CEX, relative to other surveys, is its consistent, detailed, and accurate measures of consumption outlays over a long period of time. Further, the CEX collects an inventory of durable goods and financial assets.

The CEX has been a continuous cross-sectional survey since 1980, and we use data every five years starting in 1983. To get an adequate sample size for each year, we use the four quarters of data for each year plus data from the last quarter from the year before and the first quarter for the year after. For 2003, this means we use data from the fourth quarter of 2002 to the first quarter of 2004. This allows us to have around 2,000 individuals per year. The CEX collects data from the same consumer unit over a three-month period for four consecutive quarters. The CEX uses a consumer unit of measurement, which is defined as members of a household who are related or share at least two out of three major expenditures (food, housing, 
and all other). A person living alone is a single consumer unit. (There are approximately 3 percent more consumer units than households as defined by most surveys.)

We disaggregate consumer unit information by the age of each individual within the household so that we can examine the assets and consumption of individuals by age group. We want to be able to compare consumption of individuals living in households of different size, so we adjust the consumption resources of a consumer unit by an equivalence scale, and use the consumer unit size (multiplied by the unit's sample weight) as a weight. Adjusting consumption in this manner yields "equivalent resources per person" and provides us with a sample of individuals whose resources are given by the equivalent resources of their consumer unit, which allows us to compare resources across households of different sizes. The scale we use is given by the square root of family size and indicates that the resources for a two-person family must be 41 percent more than that of a single-person family for the two families to have an equivalent standard of living.

One concern about equivalence scales for the older population is the change in family size caused by the death of a spouse. Holden (1988) first documented the importance of changing family size on the measurement of the well-being of widows. Burkhauser et al. (2005) show how income replacement rates for widows are sensitive to the chosen elasticity. The CEX has marital status including whether the individual is a widow(er), but we chose not to separate widows from other individuals because of sample size limitations.

Our chosen scale falls within the general constant elasticity scales developed by Buhmann, Rainwater, Schmaus, and Smeeding (1988). In general, the constant elasticity scales are given by (family size) $)^{e}$, in which $e$ is the scale elasticity. If the elasticity equals one, then the scale equals family size; there are no assumed economies of scale in living arrangement and the 
equivalent resources are simply the per capita resources. Alternatively, if the elasticity equals zero, then there is no adjustment for family size; there are complete economies of scale in living. Our chosen elasticity of 0.5 lies halfway between these two implausible extremes and is commonly used in the literature (e.g., Burkhauser and Smeeding, 1994; and, Burkhauser et al., 2005). We also tested the sensitivity of our results to the equivalence scale and found the results to be insensitive to the scale.

We construct 5-year cohorts from the CEX that range from ages 50-54 to 80+. We then follow their cohort characteristics at five points in time over 20 years: 1983-4, 1988, 1993, 1998, and 2003. Our youngest cohort was born between 1930 and 1934 and is aged 50-54 in 1984; we follow this cohort until they reach age 70-74 in 2003. The oldest cohort was born between 1915 and 1919 and was aged 65-69 in 1984 and is followed until they are 80-plus in 1998. The comparative disadvantage of the CEX is that it is not a longitudinal survey like the HRS. Therefore, we cannot examine the dynamics of individual behavior over time. We, however, partially compensate for this disadvantage by following four cohorts over a twenty-year period.

Cohort analysis allows us to follow the median individual within different age groups across given points in time. Cohort analysis has some built-in biases, which are similar to the biases in panel data sets. Following a single cohort over time becomes increasingly biased the longer the time period because of differential mortality rates for individuals of different social and economic status (SES). To judge the size of the bias we used education as a proxy for SES and calculated how the percentage of each cohort with a high school education or less changed as it aged. There was almost no detectable change before age sixty. The percentage of the cohort with only high school or less education, however, decreased nine percent from 65-69 to 80-plus for our oldest cohort. This means that the consumption estimates for age groups above 65-69 
will tend to overestimate consumption levels relative to what it would have been without differential mortality.

A second source of bias is in how the sampling frame changes in the very old ages. The CEX's survey sampling frame includes only the non-institutionalized population, which means that older adults who move to a long-term care facility will drop out of the sample. Although it seems likely to bias the results over time, it is hard to tell in which direction without knowing much more about the characteristics for each cohort of the very old that move into institutions. The CEX does include older individuals that might no longer live in their own home or apartment but are not institutionalized, such as when an older individual moves in with her adult child.

To examine the stock of housing, we use the property value and equity in the individual's residence. The CEX includes the current property value, the outstanding principal on all home loans, and the year the individual moved into the home, which are provided by the homeowner. Another source of concern is the respondents' optimism about the value of their home. Recent studies have suggested that homeowners may be overestimating the value of their homes by about 10 percent (Kiel and Zabel, 1999; and Venti and Wise, 2002). If homeowners do overstate the value of their home in the CEX data, median housing equity and median net worth would be overestimated in our results as well.

To examine the consumption of older adults we develop two consumption measures that differ only by how they treat the largest durable consumption good, the owned home. Our first measure, consumption-expenditures, includes only direct expenditures during the year. The issue is how to handle expenditures for durables, such as the home, which may be enjoyed many years after the expenditures on a mortgage have ended. Therefore, the second consumption 
measure treats the value of consumption of the home as a flow throughout the entire period of homeownership. More specifically:

- Consumption-expenditure equals the direct spending for current consumption. It includes expenditures for housing, food, transportation, apparel, medical care, entertainment, gifts to organizations or person outside the consumer unit, and miscellaneous items for the consumer unit. Excluded are expenditures for pensions and social security, savings, and life insurance.

- Consumption-flow reflects current direct consumption plus the rental value of the home rather than the expenditures for the home. (Consumption-flows equal consumptionexpenditures minus the costs of home expenditures plus the rental equivalence of the owned home.) Although data for other durables exist, the flows are much smaller and will not affect the conclusions. For renters, consumption-expenditures equal consumption-flows and both include rental payments.

The concepts of consumption expenditures and flows both include direct home maintenance, repairs, insurance, and utilities. For homeowners, consumption-expenditures also include payments for mortgage interest and property taxes. Housing flows, however, replace mortgage interest and property taxes with the rental value of the home. The rental equivalence value of the home equals the amount the individual's home would rent for unfurnished on today's market, excluding utilities. The respondent provides the rental estimate, which may have the same upward bias as the homeowners' estimates of the value of their home. 
Finally, we present median instead of mean equivalent expenditures and flows because of the skewed distribution of assets and consumption. All asset and consumption data are in real 2003 dollars, using the item indexes from the CPI research series (CPI-U-RS).

\section{RESULTS}

Asset Value of Housing for Older Adults

Between 1984 and 2003, a large majority (81-89 percent) of our four cohorts were homeowners (Table 1). The CEX estimates of the percent of older adults that are homeowners are consistent with estimates made from the SIPP (Venti and Wise, 2002), but these estimates are somewhat higher than estimates from the American Housing Survey (AHS). The AHS reports the percent of older adult households that own their home and the CEX estimates are of the number of older adult individuals who own a home. When we aggregated the CEX individuals to consumer units, we find numbers that are closer to the AHS estimates. For example in 1998 we find that 82.0 percent of 65-69 year olds and 83.4 percent of 70-74 year olds own a home, while the AHS reports 84.2 and 83.6 respectively. The CEX shows no significant decrease in the percentage of older adults who are homeowners until after age 80, and even then the decreases are small.

Of those older adults aged 65-69 years old who own a home, less than a third had a mortgage and that fraction continues to decrease with age (Table 1). Because of the high ownership rate and the declining percentage of homeowners with mortgages the older adult's home equity increases over time for three of the cohorts, and equity for cohort 3 remained relatively stable over the twenty years (Table 2). Masnick, Di, and Belsky (2005) also show increases in home equity between 1989 and 2001 using SCF data, and Venti and Wise (2002) found a similar pattern using SIPP data. 
Part of the increase in home equity can be attributed to the long housing tenure of older adults. The CEX asks homeowners when they bought their house, and we calculate tenure from the date of purchase to the date of the survey. Median years of tenure increase with age for our cohorts, suggesting that few older adults in each cohort are selling their homes and moving into other homes (Table 2). This is consistent with the 1999 AHS estimates that only about 4 percent of 62-plus homeowners moved in the year of the survey. Of those who moved, factors such as climate were much more important than financial considerations such as taxes and public services (Duncombe, Robbins, and Wolf, 2003).

Despite the absolute increase in home equity after age 60-64, few older adults have converted their housing stock into consumption with home equity loans as of 2003 (Table 1). When including second mortgages with home equity loans, the percentage that could be using home loans to finance other consumption increases to 12 percent of older adults aged 65-69 in 2003. The AHS estimates that 9 percent of 65-69 year olds had home equity loans in 2001. Median net worth for 65-69 year olds varies from $\$ 100,000$ to $\$ 180,000$ for the four cohorts over the twenty-year period (Table 2). These estimates of median net worth are roughly consistent with median estimates of assets based on AHEAD (Anderson, French and Lam, 2004), but they are lower than estimates of net worth found in the SCF, which one might expect given that the SCF measures net worth better than other surveys.

For each cohort, there is at least a four-fold difference between home equity at the $25^{\text {th }}$ percentile of the home equity distribution and home equity at the $75^{\text {th }}$ percentile, with the younger cohorts exhibiting a larger difference at age 65-69 (Table 3). This is consistent with general economy-wide increases in wealth inequality between 1984 and 1998 noted in the SCF and elsewhere (Kennickell, 2002, 2006). Home equity as a percentage of net worth is more 
similar across the percentiles than are home equity levels. Home equity is the single most important asset in the four cohorts' net worth except at the $25^{\text {th }}$ percentile of home equity. The Consumption Value of Housing for Older Adults

The consumption value of older adult's home is the other side of the coin from home equity. In order to examine consumption of older adults, we use the two measures of consumption described in the data section - consumption-expenditures and consumption-flows. For non-housing consumption, the two measures are identical. For housing, consumptionexpenditures measure the outlays for housing expenses, and consumption-flows measure the flow of services from owned homes. Housing outlays as a percentage of total consumptionexpenditures stays relatively constant around 30 percent for all ages and cohorts (Table 4). Conversely, housing consumption-flows increase after age 60-64 for each cohort. Housing flows are consistently higher than are housing consumption-expenditures, and this difference increases as each cohort ages. Although many older adults are staying in the same home as they age, the flow of services from the home increases as the rental value of the home increases.

The share of housing consumption-expenditures and housing consumption-flows as a percentage of total consumption-expenditures and consumption-flows are remarkably consistent across homeownership percentiles and across ages (Table 5). Housing is a modestly higher share of both expenditures and flows for the $25^{\text {th }}$ percentile than the $75^{\text {th }}$ percentile, but in general it plays a large and stable role across the distribution. One thing that changes is the percentage of total consumption-flows dedicated to housing flows. This percentage increases for each cohort as it ages as the rental value of home increases and because non-housing consumptionexpenditures decrease after age 60-64. 
We might expect non-housing consumption to decrease because housing consumption is constant or increasing (Table 4) and assets are not decreasing dramatically (Table 2). As income is decreasing in retirement, we might expect non-housing consumption to suffer. Non-housing consumption is shown to slowly decline for each cohort as they age (Table 4). The average decreases per year are relatively small ranging from a 0.5 percent decrease per year for cohort 1 and cohort 2 to a 1.8 percent decrease per year for cohort 3 . For cohort 3 and cohort 4 , a large proportion of the decrease in non-housing consumption occurs after age 80. Similar patterns are seen at the $25^{\text {th }}$ percentile and $75^{\text {th }}$ percentiles, with average yearly declines in non-housing consumption at these percentiles never exceeding 1.5 percent. Between ages 60-64 and 75-79, non-housing consumption for the median individual decreased by 1.4 percent per year, while the consumption of housing flows increased by 1.3 percent per year.

While median non-housing consumption for older adults may be falling, it is only decreasing by 1 percent per year. Between 60-64 years old and 80-plus medical expenses increase about 54 percent for the median consumer unit in Cohort 3 from about \$1,900 to \$2,900 (or about a 2 percent increase per year). That is offset by decreases in consumption-expenditures for food, transportation and all other consumption of 23 percent from $\$ 8,800$ to $\$ 6,800$ (or about a 1 percent decrease per year). Nieswiadomy and Rubin (1995) found similar patterns for the consumption of older adults between 1972-72 and 1986-87.

\section{Comparing Homeowners and Renters}

This paper has focused on the behavior and economic changes within the home-owning older Americans. As each successive table has shown the economic circumstances of older adults in more detail, questions arise about the older adults who are not captured by the homeownership data, the non-homeowners. Table 6 compares the absolute differences in the 
median of a series of economic variables between homeowners and non-homeowners. Of course, these two populations are not random distributions within the U.S. population, but the comparison is particularly important in focusing on how the home represents a fundamental dividing line in the well-being of older adults.

Homeowners have higher median income, consumption-flows, and net worth than the non-homeowners for every age in every cohort in every year (Table 6). The differences are smallest for consumption-expenditures and largest for net worth. This pattern is also generally true when comparing relative differences. The largest percentage difference between owners and renters is in their net worth, and the smallest percentage difference is most often consumptionexpenditures. Over time, the differences decline for everything but consumption-flows and net worth. This is to be expected because net worth includes the equity value of the home and the consumption-flows include the rental value of the home.

At every percentile and at every age, homeowners are better off than renters are for equivalent disposable income and equivalent consumption-flows. In results not shown in Table 6 , at every age median consumption-flows for renters is lower than the $25^{\text {th }}$ percentile consumption-flow for homeowners. The differences between renters' and homeowners' disposable income shrink with age while their differences in consumption-flows grow with age (Table 6). This could be partly a function of the changing composition of each group because of differential mortality. For instance, if the poorest renters die sooner than other renters or homeowners then the differences would shrink, but they never disappear.

\section{DISCUSSION}

This analysis shows stable homeownership rates for older adults; this is consistent with recent work using the Survey of Income and Program Participation (Venti and Wise, 2002). The 
results also show increasing mortgage-free homeownership, low numbers of home equity loans, and long tenure in their homes for four cohorts of older Americans over 20 years. While this is occurring, homeowners are able to maintain their housing and non-housing consumption well into their 70s. All of this suggests that there really is 'no place like home' for older Americans. We argue that the older population may be holding on to their homes for several reasons:

- They may want to provide their children with an inheritance, consistent with a bequest motive;

- The older they become, the more that adults may want to stay in a place that has emotional meaning and memories, which would be consistent with the socioemotional selectivity hypothesis;

- They may want to hold on to their home because it is liable to be the highest performing asset in their portfolio, especially in recent years.

- They may want to hold on to their home because they may be facing one last major consumption expense, long-term care. And consistent with the life-cycle hypothesis they may want to ensure that they have enough assets at the end of their life to finance this last major consumption need.

The CEX data cannot distinguish among these different motives because it follows cohorts over time. Only longitudinal data sets, which follow the same individuals over a long period and which contain data on the aspirations and actual disposition of housing assets, will be able to draw more definitive conclusions about motives. Longitudinal data will also be able to evaluate whether a significant portion of older people transfer the deed of their home to a younger family member while staying in the home. And only longitudinal data that include the institutional 
population will be able to determine whether people are using their home as long-term care insurance. Because the CEX does not include this critical transition in the lives of the older population, it can only hint at its importance rather than describe it.

A recent study of homeownership rates over time in seventeen developed countries suggests that the housing behavior of older Americans is anomalous (Chiuri and Jappelli, 2006). Homeownership dropped between the ages of 51-60 and 71-80 by an average of 26 percent in the sixteen other countries studied. Canada, the United States' closest neighbor and largest trading partner, had about the same rate of homeownership as the U.S. (78.6 percent vs. 76.5 percent respectively) in the age group 51-60, but by ages 71-80 Canadian homeownership rates declined 25 percent while the U.S. dropped only 6 percent (Chiuri and Jappelli, 2006). There may be many reasons for these international differences, such as the treatment of estate taxes. A full understanding of these differences is beyond the scope of this paper. One possible future research issue is to explore the locus of responsibility for the last major consumption item in many people's lives, the expenses of long-term care.

In most countries long-term care expenses are either the responsibility of the government or a shared responsibility based on the income of the recipient. In the U.S. long-term care expenses are the responsibility of the recipient, not the government. Only if the patients are living on a minimum income and have spent down their assets can they become eligible for public assistance for long-term care. In the United States, Kemper and Murtaugh (1991) estimate that after age 65 , about 7 percent of men and 20 percent of women will experience a two-year or longer stay in a long-term care facility before their death. The values of home equity at the first, second, and third quartiles are about $\$ 50,000, \$ 100,000$, and $\$ 150,000$ respectively 
(Table 3). These amounts correspond roughly to one, two, or three years in long-term care facility (Metropolitan Life Insurance Company, 2003).

That suggests that the biggest consumption-expenditure in the life of older Americans may still be ahead of them if they have to pay for long-term care. The CEX cannot explore this question in more detail because like most surveys its sampling frame is restricted to the noninstitutional population. Only the HRS, which is not restricted, will be able to observe this last stage of the life-cycle for their survey participants, and therefore evaluate the life-cycle hypothesis over the framework of a completed life. 


\section{REFERENCES}

Anderson, K., French E., \& Lam, T. (2004). You can't take it with you: Asset run-down at the end of the life cycle. Economic Perspectives, 3, 40-54.

Bucks, B., Kennickell, A., \& Moore, K. (2006, March 22). Recent changes in U.S. family finances: Evidence from the 2001 and 2004 Survey of Consumer Finances. Federal Reserve Bulletin, A1-A38.

Buhmann, B., Rainwater, L., Schmaus, G., \& Smeeding, T. M. (1988). Equivalence scales, wellbeing, inequality, and poverty: Sensitivity estimates across ten countries using the Luxembourg Income Study (LIS) database. Review of Income and Wealth, 34, 115-142.

Burkhauser, R. V., Giles, P., Lillard, D. R., \& Schwarze, J. (2005). Until death do us part: An analysis of the economic well-being of widows in four countries. Journal of Gerontology: Social Sciences, 60, S238-S246.

Burkhauser, R. V., \& Smeeding, T. M. (1994). Social Security reform: A budget neutral approach to reducing older women's disproportionate rise of poverty. Center for Policy Research Policy Brief No. 2.

Butrica, B. A., Goldwyn, J. H., \& Johnson, R. W. (2005, January). Understanding expenditure patterns in retirement. Center for Retirement Research at Boston College Working Paper No. 2005-03.

Carstensen, L. L. (2006). The influence of a sense of time on human development. Science, 312, 1913-1915.

Chiuri, M. C., \& Jappelli, T. (2006, May). Do the elderly reduce housing equity? An international comparison. Centre for Studies in Economics and Finance Working Paper No. 158. 
Duncombe, W., Robbins, M., \& Wolf, D. A. (2003). Place characteristics and residential location choice among the retirement-age population. Journal of Gerontology: Social Sciences, $58, \mathrm{~S} 244-\mathrm{S} 252$.

Fisher, J. D., Johnson, D. S., Marchand, J. T., Smeeding, T. M., \& Torrey, B. B. (2005, June). The retirement consumption conundrum: Evidence from a consumption survey. Center for Retirement Research at Boston College Working Paper No. 2005-14.

Garner, T., Hurd, M. D., Paszkiewicz, L., \& Rohwedder, S. (2005). Comparing spending measures in the CES and CAMS. On-going research at RAND and the Bureau of Labor Statistics.

Henderson, J. V., \& Ioannides, Y. M. (1983). A model of housing tenure choice. American Economic Review, 73, 98-113.

Holden, K. (1988). Poverty and living arrangements among older women: Are changes in economic well-being underestimated? Journal of Gerontology: Social Sciences, 43, S22S27.

Hoynes, H. W., \& McFadden, D. (1997). The impact of demographics on housing and nonhousing wealth in the United States. In M. D. Hurd \& N. Yashiro (Eds.), The Economic Effects of Aging in the United States and Japan (pp. 153-194). Chicago: University of Chicago Press.

Johnson, D. S., Smeeding, T. M., \& Torrey, B.B. (2005). Economic inequality through the prisms of income and consumption. Monthly Labor Review, 128, 11-24.

Kemper, P., \& Murtaugh, C. (1991). Lifetime use of nursing care. New England Journal of Medicine, 324, 595-600. 
Kennickell, A. (2002, August). Demographic shifts in the distribution of wealth, 1992 to 1998: Evidence from the survey of consumer finances. Survey of Consumer Finances Working Paper.

Kennickell, A. (2006, June). Currents and undercurrents: Changes in the distribution of wealth, 1989-2004. Survey of Consumer Finances Working Paper.

Kiel, K. A., \& Zabel, J. E. (1999). The accuracy of owner provided house values: The 1978-1991 American Housing Survey. Real Estate Economics, 27, 263-298.

Kutty, N. K. (1998). The scope for poverty alleviation among elderly home-owners in the Untied States through reverse mortgages. Urban Studies, 35, 113-129.

Masnick, G. S., Di, Z. X., \& Belsky, E. S. (2005, January). Emerging cohort trends in housing debt and home equity. Joint Center for Housing Studies Working Paper No. W05-1.

Metropolitan Life Insurance Company. (2003). The MetLife Market Survey of Nursing Home \& Home Care Costs. Retrieved April 12, 2006, from MLIC Web site: http://www.metlife.com/WPSAssets/22802718901060258447V1F2003\%20NH\%20HC\% 20Market\%20survey.pdf

Modigliani, F., \& Brumberg, R. (1954). Utility analysis and the consumption function: An interpretation of cross-section data. In K. K. Kurihara (Ed.), Post-Keynsian Economics (pp. 388-436). New Brunswick, NJ: Rutgers University Press.

Munnell, A. H., \& Soto, M. (2005, December). The house and living standards in retirement. Center for Retirement Research at Boston College Issue in Brief No. 39.

Nieswiadomy, M., \& Rubin, R. M. (1995). “Change in expenditure patterns of retirees: 1972-73 and 1986-87. Journal of Gerontology: Social Sciences, 50, S274-S290. 
Skinner, J. S. (1996). Is housing wealth a sideshow? In D. A. Wise (Ed.), Advances in the Economics of Aging (pp. 241-268). Chicago: University of Chicago Press.

Venti, S. F., \& Wise, D. A. (2002). Aging and housing equity. In O. S. Mitchell, Z. Bodie, P. B. Hammond, and S. Zeldes (Eds.), Innovations in Retirement Financing (pp. 254-281). Philadelphia: University of Pennsylvania Press.

Venti, S. F., \& Wise, D. A. (2004). Aging and housing equity: Another look. In D. A. Wise (Ed.), Perspectives in the Economics of Aging (pp. 127-175). Chicago: University of Chicago Press.

Walker, L. (2004, January). Elderly households and housing wealth: Do they use it or lose it? University of Michigan Retirement Research Center Working Paper No. 2004-070. 


\section{TABLE 1}

\section{HOMEOWNERSHIP STATUS BY COHORT AND AGE}

COHORT 1
Own home
$\%$ with a mortgage
$\%$ with a home equity loan

\section{COHORT 2}

Own home

$\%$ with a mortgage

$\%$ with a home equity loan ${ }^{\mathrm{a}}$

\section{COHORT 3}

Own home

$\%$ with a mortgage

$\%$ with a home equity loan ${ }^{\mathrm{a}}$

\section{COHORT 4}

Own home

$\%$ with a mortgage

$\%$ with a home equity loan ${ }^{\mathrm{a}}$

$\begin{array}{rrrrr}\mathbf{5 0 - 5 4} & \mathbf{5 5 - 5 9} & \mathbf{6 0 - 6 4} & \mathbf{6 5 - 6 9} & \mathbf{7 0 - 7 4} \\ 1984 & 1988 & 1993 & 1998 & 2003 \\ 86.6 & 86.1 & 86.8 & 87.6 & 89.3 \\ 62.4 & 53.4 & 34.0 & 27.2 & 24.6 \\ ----- & ----- & 2.5 & 3.3 & 4.4\end{array}$

$\begin{array}{rrrrr}1984 & 1988 & 1993 & 1998 & 2003 \\ 86.5 & 86.4 & 86.7 & 89.2 & 86.5\end{array}$

$\begin{array}{lllll}86.5 & 86.4 & 86.7 & 89.2 & 86.5\end{array}$

$\begin{array}{lllll}50.7 & 36.7 & 26.1 & 24.7 & 21.3\end{array}$

$\begin{array}{lllll}---- & --- & 3.5 & 3.4 & 2.2\end{array}$

$\begin{array}{rrrrr}1984 & 1988 & 1993 & 1998 & 2003 \\ 85.2 & 84.2 & 86.3 & 86.8 & 85.5 \\ 37.6 & 29.9 & 22.8 & 20.6 & 18.0 \\ ----- & ----- & 3.1 & 1.7 & 1.6\end{array}$

$\begin{array}{llll}1984 & 1988 & 1993 & 1998\end{array}$

$\begin{array}{llll}84.8 & 82.7 & 84.9 & 80.9\end{array}$

$30.5 \quad 22.5 \quad 14.0 \quad 14.2$

---- $\quad----\quad 1.0 \quad 1.8$

${ }^{\text {a }}$ Home equity loan data is not available in the CEX before 1992.

Source: Consumer Expenditures Survey (1984-2003).

Notes: All data are in real $\$ 2003$ using the CPI-U-RS item indexes. We weight all data to be representative of the U.S. older adult population. Our unit of observation is the individual.

Cohort 1 was born between 1930 and 1934 and was 65-69 in 1998. Cohort 2 was born between 1925 and 1929 and was 65-69 in 1993. Cohort 3 was born between 1920 and 1924 and was 6569 in 1988. Cohort 4 was born between 1915 and 1919 and was 65-69 in 1983/84. The sample size is 2,588 individuals in 1984; 2,385 in 1988; 1,871 in 1993; 1,837 in 1998; and, 2,063 in 2003. 


\section{TABLE 2}

\section{HOMEOWNERSHIP STATISTICS AT THE MEDIAN OF THE HOME EQUITY DISTRIBUTION}

\section{COHORT 1}

Equity in main home

Net worth

Equity as a share of net worth

Years lived in current home

\section{COHORT 2}

Equity in main home

Net worth

Equity as a share of net worth

Years lived in current home

\section{COHORT 3}

Equity in main home

Net worth

Equity as a share of net worth

Years lived in current home

\section{COHORT 4}

Equity in main home

Net worth

Equity as a share of net worth

Years lived in current home

\begin{tabular}{|c|c|c|c|c|c|c|}
\hline 50-54 & 55-59 & 60-64 & 65-69 & 70-74 & 75-79 & 80 plus \\
\hline 1984 & 1988 & 1993 & 1998 & 2003 & & \\
\hline 77,512 & 63,526 & 67,066 & 76,960 & 85,460 & & \\
\hline 109,438 & 126,328 & 115,304 & 144,344 & 123,584 & & \\
\hline $70.8 \%$ & $50.3 \%$ & $58.2 \%$ & $53.3 \%$ & $69.2 \%$ & & \\
\hline \multirow[t]{16}{*}{19} & 21 & 20 & 26 & 27 & & \\
\hline & 1984 & 1988 & 1993 & 1998 & 2003 & \\
\hline & 78,611 & 71,136 & 86,145 & 81,305 & 89,145 & \\
\hline & 125,022 & 141,828 & 179,909 & 107,792 & 127,887 & \\
\hline & $62.9 \%$ & $50.2 \%$ & $47.9 \%$ & $75.4 \%$ & $69.7 \%$ & \\
\hline & 21 & 22 & 27 & 26 & 34 & \\
\hline & & 1984 & 1988 & 1993 & 1998 & 2003 \\
\hline & & 72,687 & 65,185 & 72,523 & 77,616 & 72,666 \\
\hline & & 116,363 & 101,536 & 100,592 & 134,164 & 100,159 \\
\hline & & $62.5 \%$ & $64.2 \%$ & $72.1 \%$ & $57.9 \%$ & $72.6 \%$ \\
\hline & & 25 & 23 & 28 & 34 & 36 \\
\hline & & & 1984 & 1988 & 1993 & 1998 \\
\hline & & & 75,034 & 67,508 & 73,436 & 80,255 \\
\hline & & & 120,250 & 168,853 & 105,209 & 126,308 \\
\hline & & & $62.4 \%$ & $40.0 \%$ & $69.8 \%$ & $63.5 \%$ \\
\hline & & & 25 & 26 & 27 & 32 \\
\hline
\end{tabular}

Source: Consumer Expenditures Survey (1984-2003).

Notes: All data are in real $\$ 2003$ using the CPI-U-RS item indexes. We weight all data to be representative of the U.S. older adult population. Our unit of observation is the individual. Cohort 1 was born between 1930 and 1934 and was 65-69 in 1998. Cohort 2 was born between 1925 and 1929 and was 65-69 in 1993. Cohort 3 was born between 1920 and 1924 and was 65-69 in 1988. Cohort 4 was born between 1915 and 1919 and was 65-69 in 1983/84. 


\section{TABLE 3}

\section{HOME EQUITY AS A PERCENTAGE OF NET WORTH BY PERCENTILES}

\section{AGE 65-69}

\author{
Home equity as \\ Home equity \% of net worth
}

COHORT 1

25th percentile

50th percentile

75th percentile

\section{COHORT 2}

25th percentile

50th percentile

75 th percentile

\section{COHORT 3}

25th percentile

50th percentile

75 th percentile

\section{COHORT 4}

25th percentile

50th percentile

75 th percentile

22,139
76,960
134,089

33.0

53.3

62.0

39.5

30,654

89,145

156,588

75.0

86,145

148,702

21,131

65,185

112,037

58.5

25,763

64.2

63.2
AGE 75-79

Home equity as \% of net worth
N/A

N/A

N/A

N/A N/A

33.5

57.9

70.6

49.4

69.7

68.5

$\begin{array}{rr}77,616 & 57.9 \\ 123,234 & 70.6\end{array}$

Source: Consumer Expenditures Survey (1984-2003).

Notes: All data are in real $\$ 2003$ using the CPI-U-RS item indexes. We weight all data to be representative of the U.S. older adult population. Our unit of observation is the individual. To calculate the mean and share of the $X^{\text {th }}$ percentile, we use a 10 percentage point band around the $X^{\text {th }}$ percentile and take the mean within this band. For the $25^{\text {th }}$ percentile, this means that we use the individuals in the $20^{\text {th }}$ to $30^{\text {th }}$ percentiles of the home equity distribution. 


\section{TABLE 4}

OUTLAYS VS. FLOWS (At the median of the consumption measure used)

\section{COHORT 1}

Housing outlay

As $\%$ of total expenditures

Housing flows

As $\%$ of total flows

Non-housing consumption ${ }^{\mathrm{a}}$

\section{COHORT 2}

Housing outlay

As $\%$ of total expenditures

Housing flows

As $\%$ of total flows

Non-housing consumption ${ }^{\mathrm{a}}$

\section{COHORT 3}

Housing outlay

As \% of total expenditures

Housing flows

As $\%$ of total flows

Non-housing consumption ${ }^{\mathrm{a}}$

\section{COHORT 4}

Housing outlay

As $\%$ of total expenditures

Housing flows

As $\%$ of total flows

Non-housing consumption ${ }^{\mathrm{a}}$

$\begin{array}{rrrrr}\mathbf{5 0 - 5 4} & \mathbf{5 5 - 5 9} & \mathbf{6 0 - 6 4} & \mathbf{6 5 - 6 9} & \mathbf{7 0 - 7} \\ 1984 & 1988 & 1993 & 1998 & 2003 \\ 4,713 & 5,214 & 4,494 & 5,727 & 4,517 \\ 27.2 & 28.9 & 27.0 & 31.8 & 28.6 \\ 7,863 & 8,365 & 7,275 & 9,556 & 9,63 \\ 38.9 & 40.2 & 37.7 & 43.1 & 45 . \\ 12,330 & 12,420 & 12,023 & 12,618 & 11,53\end{array}$

75-79

$80 \%$ change

plus from 60-64

$0.5 \%$

$32.4 \%$

$-4.1 \%$

$\begin{array}{lllll}1984 & 1988 & 1993 & 1998 & 2003\end{array}$

$\begin{array}{lllll}4,699 & 4,595 & 4,499 & 5,374 & 4,262\end{array}$

$-7.2 \%$

$\begin{array}{lllll}28.4 & 27.5 & 27.1 & 31.6 & 27.4\end{array}$

$\begin{array}{lllll}7,615 & 7,600 & 8,378 & 9,192 & 9,995\end{array}$

$31.5 \%$

$\begin{array}{lrrrr}38.5 & 38.8 & 41.2 & 44.1 & 47.0\end{array}$

$12,158 \quad 11,973 \quad 11,955 \quad 11,654 \quad 11,291$

$-5.7 \%$

$\begin{array}{rrrrrr}1984 & 1988 & 1993 & 1998 & 2003 & \\ 4,879 & 4,511 & 4,432 & 4,217 & 4,522 & -7.3 \% \\ 31.2 & 29.1 & 29.7 & 29.5 & 31.7 & \\ 8,083 & 7,644 & 7,987 & 9,313 & 10,249 & 26.8 \% \\ 43.6 & 41.5 & 42.6 & 50.0 & 52.0 & \\ 10,437 & 10,761 & 10,744 & 9,324 & 8,475 & -18.8 \%\end{array}$

$\begin{array}{llll}1984 & 1988 & 1993 & 1998\end{array}$

$4,485 \quad 3,945 \quad 3,977 \quad 4,753$

N/A

$29.1 \quad 27.1 \quad 30.0 \quad 34.7 \quad$ N/A

$7,947 \quad 8,502 \quad 7,270 \quad 9,489 \quad$ N/A

$\begin{array}{lllll}41.6 & 44.5 & 42.1 & 52.3 & \text { N/A }\end{array}$

$11,156 \quad 10,620 \quad 10,015 \quad 8,651$

${ }^{\text {a }}$ Non-housing consumption is the same for our two measures of total consumption, consumption-expenditures and consumption-flows. The two measures only differ in their treatment of housing.

Source: Consumer Expenditures Survey (1984-2003).

Notes: All data are in real $\$ 2003$ using the CPI-U-RS item indexes. We weight all data to be representative of the U.S. older adult population. Our unit of observation is the individual. To calculate the mean and share of the $\mathrm{X}^{\text {th }}$ percentile, we use a 10 percentage point band around the $\mathrm{X}^{\text {th }}$ percentile and take the mean within this band. For the $25^{\text {th }}$ percentile, this means that we use the individuals in the $20^{\text {th }}$ to $30^{\text {th }}$ percentiles of the home equity distribution. 
TABLE 5

THE IMPORTANCE OF HOUSING BY PERCENTILE

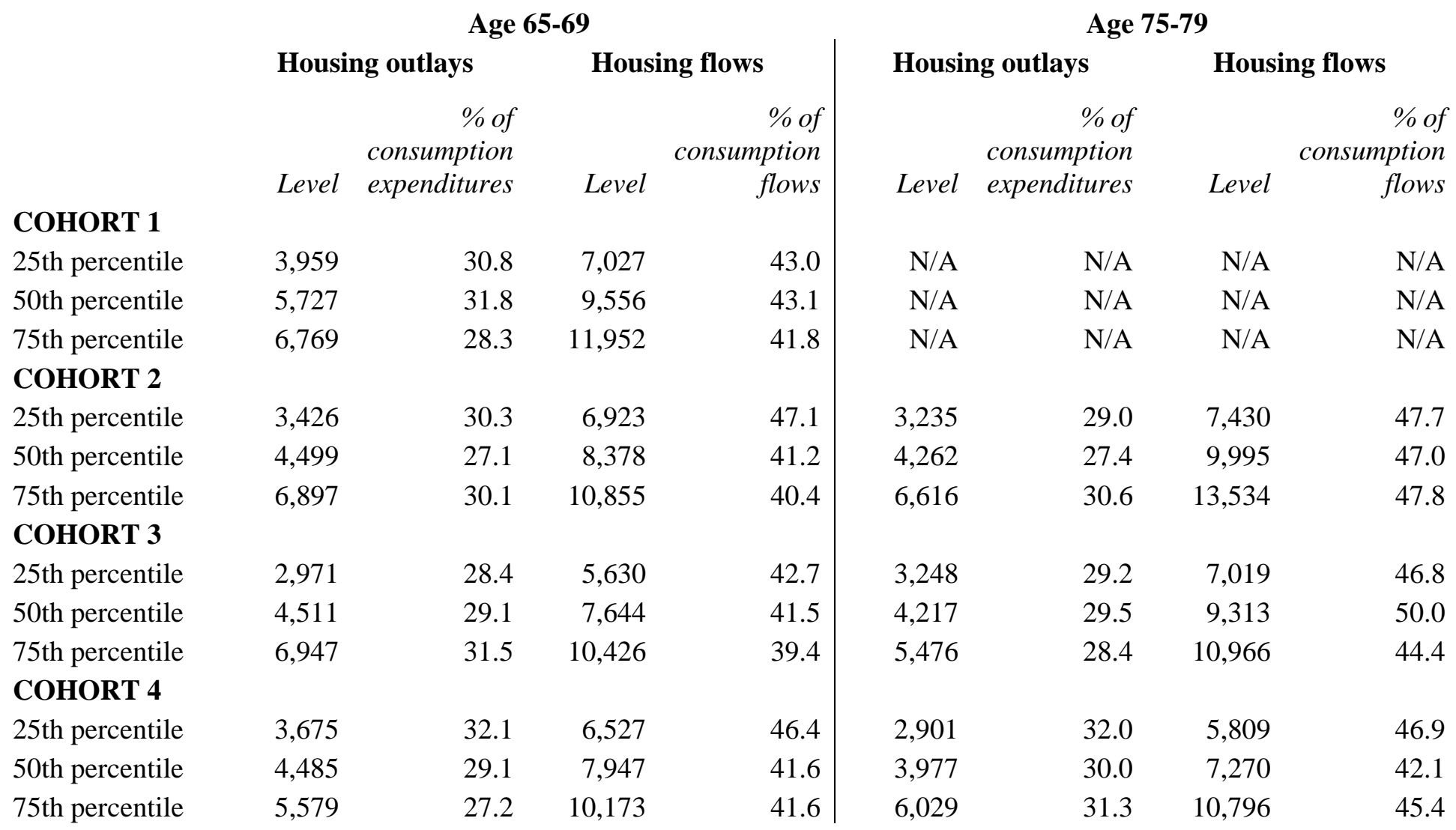

Source: Consumer Expenditures Survey (1984-2003).

Notes: All data are in real $\$ 2003$ using the CPI-U-RS item indexes. We weight all data to be representative of the U.S. older adult population. Our unit of observation is the individual. To calculate the mean and share of the $\mathrm{X}^{\mathrm{th}}$ percentile, we use a 10 percentage point band around the $\mathrm{X}^{\text {th }}$ percentile and take the mean within this band. For the $25^{\text {th }}$ percentile, this means that we use the individuals in the $20^{\text {th }}$ to $30^{\text {th }}$ percentiles of the home equity

distribution. 


\section{TABLE 6}

\section{DIFFERENCES IN MEASURES OF WELL-BEING BETWEEN HOMEOWNERS AND RENTERS (MEDIAN)}

\section{COHORT 1}

Gross income

Disposable income

Consumption expenditures

Consumption flows

Net worth less housing

Net worth

Gross income

Disposable income

Consumption expenditures

Consumption flows

Net worth less housing

Net worth

\section{COHORT 3}

Gross income

Disposable income

Consumption expenditures

Consumption flows

Net worth less housing

Net worth

\section{COHORT 4}

Gross income

Disposable income

Consumption expenditures

Consumption flows

Net worth less housing

Net worth
COHORT 2

$\begin{array}{rrrrr}\mathbf{5 0 - 5 4} & \mathbf{5 5 - 5 9} & \mathbf{6 0 - 6 4} & \mathbf{6 5 - 6 9} & \mathbf{7 0 - 7 4} \\ 1984 & 1988 & 1993 & 1998 & 2003 \\ 14,136 & 18,836 & 11,765 & 7,881 & 7,425 \\ 9,853 & 14,388 & 11,007 & 7,032 & 6,562 \\ 7,016 & 6,909 & 3,700 & 7,276 & 5,847 \\ 9,796 & 9,161 & 6,848 & 11,774 & 12,115 \\ 25,346 & 29,115 & 16,206 & 16,440 & 4,935 \\ 124,877 & 132,419 & 115,633 & 132,149 & 130,816\end{array}$

$\begin{array}{rrrrr}1984 & 1988 & 1993 & 1998 & 2003 \\ 12,622 & 8,451 & 8,350 & 7,808 & 5,720 \\ 11,904 & 6,782 & 8,209 & 7,552 & 5,190 \\ 6,525 & 6,488 & 4,293 & 5,389 & 3,706 \\ 9,106 & 7,400 & 7,145 & 10,226 & 10,388 \\ 21,370 & 22,504 & 12,506 & 13,514 & 3,159 \\ 121,066 & 130,693 & 142,289 & 124,479 & 146,872\end{array}$

$\begin{array}{rrrrr}1984 & 1988 & 1993 & 1998 & 2003 \\ 10,407 & 3,705 & 6,687 & 7,119 & 3,157 \\ 9,470 & 3,017 & 5,317 & 6,329 & 3,265 \\ 7,093 & 3,611 & 3,374 & 1,206 & 835 \\ 8,471 & 5,474 & 7,240 & 5,762 & 6,068 \\ 16,911 & 13,153 & 14,582 & 9,811 & 1,226 \\ 123,495 & 110,005 & 118,601 & 114,952 & 120,000\end{array}$

$\begin{array}{rrrr}1984 & 1988 & 1993 & 1998 \\ 6,964 & 3,383 & 5,192 & 3,277 \\ 6,184 & 2,821 & 3,887 & 3,095 \\ 3,447 & 4,946 & -1,672 & 1,572 \\ 3,103 & 6,915 & 3,451 & 6,656 \\ 17,114 & 21,788 & 3,921 & 7,002 \\ 29,466 & 130,632 & 120,237 & 120,508\end{array}$

Source: Consumer Expenditures Survey (1984-2003).

Notes: All data are in real \$2003 using the CPI-U-RS item indexes. We weight all data to be representative of the U.S. older adult population. Our unit of observation is the individual. 


\section{RECENT WORKING PAPERS FROM THE \\ CENTER FOR RETIREMENT RESEARCH AT BOSTON COLLEGE}

Effects of Public Policies on the Disposition of Lump-Sum Distributions: Rational and Behavioral Influences

William G. Gale and Michael Dworsky, August 2006

Pensions, Social Security, Wealth and Lifetime Earnings: Evidence from the Health and Retirement Study

William G. Gale and John W.R. Phillips, August 2006

Determinants and Consequences of Bargaining Power in Households

Leora Friedberg and Anthony Webb, June 2006

Earnings and Women's Retirement Security

Alicia H. Munnell and Natalia Zhivan, June 2006

Mortality Heterogeneity and the Distributional Consequences of Mandatory

Annuitization

Guan Gong and Anthony Webb, June 2006

Can Heterogeneity of Populations Explain Differences in Mortality?

James W. Vaupel, Roland Rau, Carlo Giovanni Camarda and Kristin G. von Kistowski, March 2006

Personalized Retirement Advice and Managed Accounts: Who Uses Them and How Does Advice Affect Behavior in 401(k) Plans?

Julie Agnew, March 2006

Working for a Good Retirement

Barbara A. Butrica, Karen E. Smith and C. Eugene Steuerle, March 2006

The Politics of Parallel Pensions: Lessons from the United Kingdom for the United States

R. Kent Weaver, February 2006

Cross-National Evidence on the Fiscal Burden of Public and Private Finance of Old-Age Consumption

Gary Burtless, February 2006

The Effects of Population Aging on Labor Demand

Bob Triest, Steven Sass and Margarita Sapozhnikov, February 2006

All working papers are available on the Center for Retirement Research website

(http://www.bc.edu/crr) and can be requested by e-mail (crr@bc.edu) or phone (617-552-1762). 